\title{
Creating an Individual Work Identity
}

\author{
Kate Walsh, Cornell University
}

Judith R. Gordon, Boston College

This article builds on existing research on social identity and organizational identity to theoretically examine ways individuals create their own personal work identities. Individual work identity refers to a work-based self-concept, comprised of a combination of organizational, occupational, and other identities, that affects the roles people adopt and the corresponding ways they behave when performing their work. We show how individuals' identification with their organizations and/or occupations can be used to create their work identity, and we suggest this process will be based on the degree to which membership in these groups enhances their distinction and status. We argue that these concepts depend on whether individuals view their work as jobs, careers, or callings, as well as on whether individuals pursue a traditional career strategy versus a boundaryless career one. Finally, we offer propositions exploring the impact of identity creation on individuals' job performance and turnover intentions. We discuss the implications of our ideas for not only research in organizational identity, but also for research that explores the human resource implications of organizational actions.

\section{Creating an Individual Work Identity}

Organizational identity is a growing area of research that holds potentially important implications for both individual and organizational outcomes (Corley et al., 2006; Elsbach \& Bhattacharya, 2001). Researchers have examined the concept of organizational identity, including the presence of multiple identities (Albert \& Whetten, 1985; Corley, 2004; Pratt \& Foreman, 2000; Whetten, 2006), the process by which individuals interpret their organization's identity (Bartel, 2001; Elsbach, 2004), as well as the ways in which individuals identify with organizational membership (Fuller et al., 2006; Kreiner \& Ashforth, 2004). Yet, little research has linked an organization's identity with the ways members think about themselves as they go about their work. This focus is important because it has corresponding implications for organizations, as its members act on behalf of their organizations when 
interacting with outsiders, such as clients and customers. In this paper, we begin to make this link through describing the process by which individuals as members of their organizations, as well as members of their occupations outside of their organizations, construct and act from their own work identities.

An individual's work identity refers to a work-based self-concept, constituted of a combination of organizational, occupational, and other identities that shapes the roles a person adopts and the corresponding ways he or she behaves when performing his or her work. Identities, in general, refer to "who the individual thinks he or she is and who is announced to the world in word and action" (Charon, 1992, p. 85). They are important because identities "suggest what to do, think and even feel" (Ashforth \& Kreiner, 1999, p. 417) and therefore what corresponding roles individuals assume (Katz \& Kahn, 1966). For example, in terms of their work, do physicians think of themselves primarily as hospital employees and secondarily as members of their medical profession or vice versa? Which identities do physicians enact in performing various roles at work? The identity of "hospital employee" may cause physicians to act to reduce costs, but the identity of "medical professional" may cause physicians to prescribe expensive treatments. Do high-ranking attorneys view themselves as partners in their law firms or members of the state Bar or both? Just as organizational identity reflects the "claimed central character" of an organization (Albert \& Whetten, 1985), work identity reflects the "claimed central character" of individuals when they perform their jobs and enact their careers, and consequently is manifested in specific job-related roles that influence their work-behaviors.

At the individual level of analysis, researchers have examined the complex process by which organizational members choose to identify with what they believe is their organization's central and enduring character (Ashforth \& Mael, 1989; Dutton, Dukerich \& Harquail, 1994; Mael \& Ashforth, 1992, 1995). They have also considered the implications of this process for identity management (Barker, 1998; Pratt, 2000; Pratt \& Foreman, 2000) and sensemaking among organizational leaders (Gioia \& Thomas, 1996; Golden-Biddle \& Rao, 1997). They have shown that identity can be linked with organizational commitment, loyalty, and the display of more cooperative and supportive behaviors (Adler \& Adler, 1988; Kramer \& Brewer, 1984; Mael \& Ashforth, 1992, 1995; O'Reilly \& Chatman, 1986). Yet, research to date has not specifically examined the creation or composition of an individual's work identity, that part of an individual's identity that relates to the conduct of his or her job-related, professional, or occupational activities, or the implications of this identity for organizational outcomes. Such research would address the call to consider cross-level identity issues (Albert, 1998), as well as help discern the combinations of identities that individuals may develop and evoke (Elsbach, 1998). Most 
importantly, understanding how individuals construct and act from their work identities would help organizations apply human resource initiatives in ways that evoke the highest levels of performance.

In this article, we build on existing research on social identity, organizational identity, and occupational identity to consider the way individuals create their work identities. Understanding how individuals think of themselves in the context of their work, is important because it influences the roles they adopt and their corresponding behaviors when acting on behalf of their organizations (GoldenBiddle \& Rao, 1997). We link the identity-creating process with two crucial outcomes for organizations: individuals' job performance and their turnover intentions and in doing so, bridge an important social process in which individuals naturally engage, with ways they go about their work. We discuss the implications of such a process for an organization's human resource initiatives.

This research is based on three guiding questions: (1) What specifically is the individual work identity construct, and how do individuals create it? (2) How do individuals use membership in their organizations and occupations to create their work identities? and (3) What are the organizational implications of holding a particular work identity? We answer these questions in four specific sections. In the first section, we offer a definition of the work identity construct, and through applying research in social identity and organizational identity theories, we discuss the process by which individuals create their work identities. In addition, we explore two central groups used by individuals to create their work identities, specifically organizations and occupations. Next, we consider ways membership in these groups may together, impact identity construction, specifically whether they are in congruence or conflict. We also consider the impact of individuals' work-orientations, as well as their career strategies. In the third section, we examine the implications of holding a particular work identity for individuals' job performance and turnover intentions. Finally, we discuss the implications of our work for research in organizational identity, as well as in human resource management. We conclude with directions for future research.

\section{The Construct of Individual Work Identity}

Individual work identity refers to a work-based self-concept, constituted of a combination of organizational, occupational, and other identities, that shapes the roles individuals adopt and the corresponding ways they behave when performing their work in the context of their jobs and/or careers. Individual work identity is only one aspect of an individual's many personal identities; yet it is a central one that is evoked and applied when performing a job. It refers less to ways individuals think of themselves and act outside of their work, at home or at social or recreational activities, for example. 
We propose that individuals create their work identity by incorporating the identity offered by membership in various social groups. Our ideas are rooted in social identity theory, which holds that individuals create their self-concepts, in part, when they classify themselves into distinct social groups (Turner, 1982). Each social group offers a particular member-identity, which members can choose to incorporate into their own individual identities. Social groups can include demographically based ones (i.e., race, gender, and ethnicity), as well as organizational ones, such as clubs, religious groups, places of employment, or occupations (Bhattacharya, Rao, \& Glynn, 1995; Turner, 1982). Although many types of groups exist, we focus here on the two specific ones that offer individuals a distinctive, status-enhancing identity stemming from organizations and that are central to how they perform their work: membership in their organization and occupation. Membership in other groups, of course, may contribute to an individual's work identity, but we focus specifically here on occupational and organizational identities as primary contributors and as a major, although first step, in developing the work identity construct.

\section{Creating an Individual Work Identity}

Social identity theory explains how and why individuals might create a work identity. According to this theory, individuals create their self-identity through first comparing themselves with one another and then classifying themselves and others into different social groups (Abrams \& Hogg, 1990; Tajfel, 1982; Tajfel \& Turner, 1985; Turner, 1982; Turner, Hogg, Oakes, Reicher, \& Wetherell, 1987). In doing so, they attach value to these categories (Pettigrew, 1986). Thus, their social identities represent individuals' sense of both belonging to and differentiating from their community and culture (Hewitt, 1989). Social groupings enable individuals to distinguish themselves as different from out-group members, yet at the same time as similar to their other desirable in-group members (Ericson, 1980; Hogg \& McGarty, 1990). Through social identity, individuals make sense of their social environment, as well as locate a place for themselves within it. Individuals have a strong desire to select identities that positively reinforce themselves, specifically their self-image (Ashforth \& Kreiner, 1999; Hogg \& White, 1995). They work toward maintaining an optimal level of distinction for themselves, whereby they select membership in social groups that are inclusive yet also distinctive, and in doing so maintain a sense of both social belonging and individuality (Brewer, 1991). For example, individuals may be attracted to membership in groups that are large enough that most people recognize them, but small enough that they offer a sense of uniqueness.

Creating an identity through socially comparing oneself with others, often through the groups to which the person belongs and does not belong, is a continuous self-defining process. Identities are 
defined and redefined as individuals interact and associate with others (Charon, 1992; Wharton, 1992) and therefore are always subject to change and development. "It [identity] arises in interaction, it is reaffirmed in interaction and it is changed in interaction" (Charon, 1992, p. 85). The process of social identity represents for individuals an ongoing process of self-construction that reflects multiple and complex dimensions (Gergen, 1991; Fine, 1994; Hewitt, 1989). For example, one individual can have many identities that confer different roles, such as the aggressive corporate manager, the loving parent, the loyal spouse and the caring child.

Yet as it relates to an individual's work identity, we argue that the process of work identity creation, while continually ongoing and shifting, at the same time can be delineated. We believe that individuals create their work identity through consciously determining the work groups, such as their organizations and occupations, whose membership most enhances their self-concept, as it relates to their work and career. They do so by interpreting first the identity that membership in each group offers and next the degree to which this identity resonates with them, a process termed organizational identification. We argue that individuals will use their organization's distinguishing competency and/or their occupation's positive defining values to determine their organization's and occupation's identity. The groups whose competencies and positive defining values offer members the greatest distinction and status enhancement, features argued to be central to identity attractiveness (Dutton et al., 1994; Dukerich, Golden \& Shortell, 2002), will be prominent for these individuals and will be used by them to create their individual work identities. Fig. 1 depicts the process of creating a work identity, outlined through our foundational propositions discussed next, as well defines the constructs we use in our arguments, specifically individual work identity, an organization's and occupation's identity and organizational and occupational identification. 
THE PROCESS OF CREATING AN INDIVIDUAL WORK IDENTITY

Propostions $\# 2$ - 4

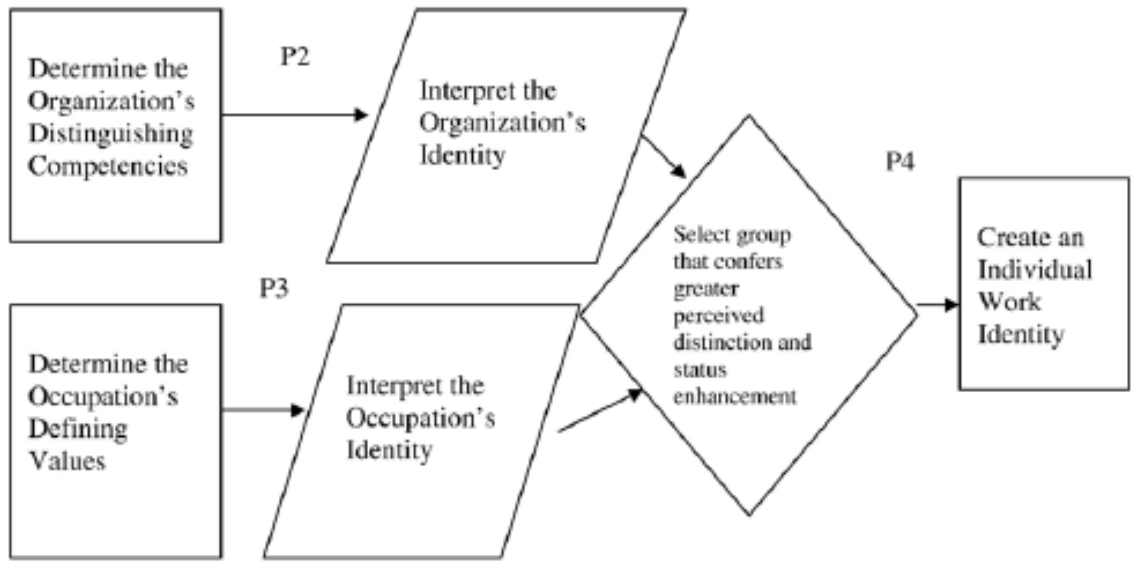

IDENTITY CONTRUCTS

$\begin{array}{ll}\begin{array}{l}\text { Construct } \\ \text { Individual Work Identity }\end{array} & \begin{array}{l}\text { Definition } \\ \text { A work-based self concept constituted of a } \\ \text { constellation of organizational, occupational and } \\ \text { other identities that shapes the roles individuals } \\ \text { adopt and the corresponding ways they } \\ \text { behaves when performing their work. }\end{array} \\ \text { Organizational or Occupational Identification } & \begin{array}{l}\text { The process by which members choose to } \\ \text { identify with membership in their organizations } \\ \text { or occupations. It refers to a cognitive } \\ \text { connection between members' perceptions of } \\ \text { their organization's or occupation's identity and } \\ \text { their self-concept. (Dutton et al., 1994). }\end{array} \\ \text { Organization or Occupational Identity } & \begin{array}{l}\text { An organization's or occupation's central, } \\ \text { distinctive, and enduring character (Albert and } \\ \text { Whetten,1985). }\end{array}\end{array}$

Fig. 1. The process of creating an individual work identity.

\section{Contributions from Organizational Identity Theory}

Organizational identification, or the degree to which individuals identify with membership in their organizations, refers to a cognitive connection between members' perceptions of their organization's identity and their self-concept (Dutton et al., 1994). Phrased a second way, it refers to the relationship employees have with their organizations (Ashforth \& Mael, 1989; Scott \& Lane, 2000) and "is said to occur when an individual's beliefs about the organization become self-referential or selfdefining" (Pratt, 1998, p.179). Organizational identification is both a socially constructed and complex, multiplex phenomenon (Albert \& Whetten, 1985; Ashforth \& Mael, 1996; Pratt, 2000; Wharton, 1992).

In determining the degree to which they identify with membership in their organizations, individuals first decide what they believe is their organization's identity. This subjective process is 
relative and comparative. Through both formal organizational practices and informal social interactions among organizational members, individuals determine what they believe is their organization's central and enduring character (Albert \& Whetten, 1985). Organizational identity is an "intersubjective construct...it cannot exist unless people agree it exists" (Ashforth \& Mael, 1996, p. 26, emphasis in original.) Yet at the same time, any statement of an organization's identity represents one member's claim or interpretation (Ashforth \& Mael, 1996). Moreover, even though individuals may state their organization's central character in relatively simple and coherent terms, both the process by which they select these terms and the meanings they ascribe to them are relatively complicated (Albert \& Whetten, 1985; Ashforth \& Mael, 1996). For example, individuals may create their definition of their organization's identity through a variety of processes, such as through casual conversations with coworkers at the coffee station, listening to news reports about their company, and interpreting a speech given by the head of their division. In both a conscious and subconscious manner, they form interpretations about their organization's central character.

Once they do so, individuals then match their own beliefs against the organization's and determine the degree to which they define themselves by the same characteristics that they believe define their organizations (Ashforth \& Mael, 1996; Dutton \& Penner, 1993; Van Maanen \& Schein, 1979). If these characteristics provide members with distinction and enhanced status that positively reinforces their self-concepts, individuals are likely to strongly identify with membership in their organizations (Dukerich et al., 2002; Dutton et al., 1994).

\section{Limitations of Organizational Identity Research}

Organizational identity research explains how and why members chose to identify with membership in various groups within the organization, including the organization itself. Through suggesting that individuals choose to identify with membership in groups that resonate most strongly with them and enhances their self-concept, it serves as an important beginning point. Yet organizational identity theory explores mostly the ways in which the relationship between the individual and organization is created and maintained (i.e. Dutton et al., 1994; Elsbach, 2003; Fuller et al., 2006; Glynn, 2000; Kreiner \& Ashforth, 2004.) While some research in organizational identification begins to examine the behavioral implications of identifying - or not identifying - with organizational membership (i.e. Bhattacharya et al., 1995; Dukerich et al., 2002; Elsbach \& Bhattacharya, 2001), the theory does not sufficiently explain the link between ways members identify with their organization and as a result, the ways they behave differently with outsiders, such as crucial clients and customers, as they perform their 
jobs. This link can be explained through examining the process by which individuals create and act from their own work identities, which is the purpose of this paper.

As the next step in explaining the process of work identity creation, we apply a foundational concept from social identity theory, that is, that individuals choose to identify with membership in social groups that positively reinforces themselves (Ashforth \& Kreiner, 1999; Hogg \& White, 1995; Tajfel, 1982). We explore two work groups that may act as prominent sources for individuals when creating their work identity: the individual's organization and occupation. We discuss how and why this process may occur.

\section{Distinction and Status Enhancement in Individual Work Identity Creation}

What causes individuals to use the identity of a group, such as an organization or occupation, to create their own work identity? We argue that a key factor that influences the process of identity creation is distinction and status enhancement. Group identities that are quite distinct or statusenhancing to individual members are more likely to be adopted and expressed by them, especially if these perceived qualities enhance members' self-image (Ashforth \& Mael, 1989; Dutton et al., 1994; Mael \& Ashforth, 1992; Rindova \& Schultz, 1998; Turner, 1981). As social identity theory suggests, individuals have a desire to maintain a positive self-image (Hogg \& White, 1995). If they perceive that membership in their organization enables them to differentiate themselves from non-group members in a positive way, they will likely use these identities to create their own work identity. By identifying themselves as group members, individuals will feel prestigious and unique compared with outsiders (Ashforth \& Mael, 1989). As organizational identification researchers offer, "the group's standing reflects on the self (and) as a consequence, because people desire a positive self-image, people tend to identify more with high status groups and organizations" (Van Knippenberg \& van Schie, 2000, p. 138). Thus, in an effort to maintain and enhance a positive work-related self-image, when creating their work identity, individuals will be more likely to use the identities of the work groups that offer them the greatest perceived levels of distinction and status enhancement. This logic leads to our first research proposition:

Proposition \#1: The greater its perceived distinction and status enhancement, the more likely members will use that group's identity to create their own individual work identities. 


\section{Organizational Competencies and the Creation of an Individual Work Identity}

Given that distinction and status enhancement contribute to group identity attraction and, we argue, individual identity creation, logically organizational members will determine their organization's identity by focusing on what makes their own organization unique and special. We argue that the characteristics that make an identity unique and special are rooted in an organization's competencies. Research in strategy and more specifically, resource-based theories of the firm, considers over time which key organizational competencies enable an organization to differentiate itself from its competition and create the distinguishing features that are central to its success (Barney, 1991; Dutton \& Penner, 1993; Mahoney \& Pandian, 1992; Nelson \& Winter, 1982; Peteraf, 1993). Competencies represent a firm's ability to make superior use of its resources relative to its competition. They represent a source of firm heterogeneity and many times, act as the firm's source of advantage (Prahalad \& Hamel, 1990). These competencies must be valuable and rare to the industry, as well as unique to the organization. In other words, they must have "imperfect imitability" whereby competitors cannot replicate them (Barney, 1991). Such competencies are unique to a firm and difficult to substitute replace (Barney, 1991; Coff, 1997). Hence, they act a source of firm-distinction and ultimately explain a firm's ability to sustain its performance.

When organizational competencies contribute to the firm's success, reputation, and, ultimately, sense of differentiation and distinction from other organizations, social identity and organizational identity theories imply they will also be used by members to determine their organization's identity (Dukerich et al., 2002). We argue they will also act as sources of individual work identities for its members. Based on the notion that individuals seek membership in organizations that will enhance their own sense of distinction, status enhancement, and ultimately, self-image (Bartel, 2001; Pratt, 1998; Tyler, 1999), we argue that organizational members will use their interpretation of the organization's differentiating competency to determine not only their organization's identity, but also to shape their own individual work identity, because this competency enables them to create a distinctive self-image relative to others, especially outgroup members. More specifically, individuals will be attracted to competencies that differentiate an organization from its competition and act as its source of competitive advantage. Hence, we offer the following:

Proposition \#2: An organization's differentiating competency will be used by members to interpret their organization's identity and, in turn, create their own individual work identities. 


\section{Occupational Values and the Creation of an Individual Work Identity}

Individuals might rely solely on organizational identification to create their work identity if there were no competing forces. But for many individuals their occupation also contributes to their work identity. Ashforth and Kreiner (1999, p. 417) define occupational identity as "the set of central, distinctive and enduring characteristics that typify the line of work." They argue that occupational identities and their associated roles are very central to organizational members and can form the basis for a strong culture. Research in occupational culture and communities (i.e., Trice, 1993; Van Maanen \& Barley, 1984) also suggests that occupations tend to form their own cultures, separate and distinct from an organization's culture. These cultures can encourage ethnocentrism and a sense of group superiority. They also guide the values, norms, and belief systems members use to judge their own and others' behaviors (Van Maanen \& Barley, 1984).

An occupation's tendency to develop a strong ideology or culture has a number of sources. It is based in part upon the occupation's unique set of codes, such as norms, values, and language, from which members develop their specialties or expertise (Van Maanen \& Barley, 1984; Zola \& Miller, 1973). Occupations, whether they are perceived as high status, such as doctors, or as low status, such as trash collectors, establish "rigorous socialization experiences... underscoring that the knowledge, skills and abilities are not easily learned by just anyone and that they require a special learning experience and a special person to grasp them" (Trice, 1993, p. 26). This strong ideology is also enhanced by the fact that occupational members tend to use one another as a reference group in not only admitting new members, but also in evaluating the contribution of current members, and hence assessing each member's level of expertise. A rigorous evaluation process helps create an internal value system that guides the norms and behaviors of its members.

Based on its cultural ideology, occupational membership can act as a strong source of an individual's work identity. Occupations provide members with a sense of group cohesion that distinguishes them from other social groups (Zola \& Miller, 1973). As Van Maanen and Barley (1984, pp. 298-299) argue, "in occupational communities, the social identities assumed by most members include...one based upon the kind of work they do and, as such, it is often quite central in the presentations of self to others...occupational identities are typically presented to others with some pride." Indeed, Ashforth and Kreiner (1999) explored how members of stigmatized occupations, such as custodians, are likely to form a strong occupational culture, transform the meaning of their work, and in doing so construe an esteem-enhancing occupational identity. They argue that given members' desires to enhance their self-concept, they will reframe, recalibrate, or refocus their occupation's ideology, 
standards, and features to justify the value of their work and create a positive associated occupational identity, as much as for themselves as for outsiders (Ashforth \& Kreiner, 1999).

This notion that members of occupations find and use some specific value in the nature of their work to construe a positive occupational identity leads to our next research proposition. We argue that members will also focus on their occupations' defining values to interpret their occupation's identity and construe their own work identity. In focusing on a positive value to form an interpretation of their occupation's identity, individuals seek to maintain their own sense of distinction and status enhancement relative to non-members. Hence we hypothesize:

Proposition \#3: An occupation's positive, defining values will be used by members to interpret their occupation's identity, and, in turn, create their own individual work identities.

\section{The Congruence or Conflict of Organizational and Occupational Identities}

Both the organization and occupation may act as significant groups that individuals use to create their work identity. As we mentioned, individuals may also use membership in other groups (such as those based on gender, age, ethnicity, or organizational subgroup) to create their work identity; however, we highlight the two primary sources that offer a sense of distinction and status enhancement and thus serve to enhance individuals' self-concepts, to suggest the complexity of work identity and its creation. Identification is not a zero-sum process (Reichers, 1985); the organization and the occupation are not mutually exclusive groups, and individuals may use both to create their work identity (Grey, 1998). In this section, we further explore the identity creation process by considering not only the combination of two work identities individuals may hold (Elsbach, 1998), but their varying strength.

Researchers have examined the influence of membership in both the individuals' organizational and occupational groups. In particular, they note the conflict of working within the constraints of a bureaucratic organization, yet at the same time fulfilling requirements and acting as a member of a larger occupation or profession (Barley, 1996; Grover, 1993; Johnson, Morgeson, Ilgen, Meyer \& Lloyd, 2006). For example, Wallace $(1993,1995)$ examined the strength of professional and organizational commitment. She found both to be significant for professionals working within organizations. Conlon and Gallagher (1987) examined employees' levels of commitment to their organization and their union and found that, depending on the group within the organization, commitment to their union varied in strength. Covaleski, Dirsmith, Heian, and Samuel (1998) examined pressures that accountants in Big Six public accounting practices felt to conform to the behavioral norms of the organization, in contrast to the behavioral norms of their profession. Russo (1998) examined the strength of organizational and 
professional identification for newspaper journalists and found that, while journalists identified more strongly with membership in their profession, both their profession and organization offered strong identities to its members.

All of this work suggests that it is possible that individuals can be members of both occupations and organizations that confer both high and low levels of perceived distinctiveness and status. (See Table 1, which details what individuals might do when they perceive their organizations and occupations to vary in their degree of distinction and status enhancement). For example, an individual could be a renowned doctor at one of the most prestigious medical practice in the country. In such a case, this individual would be a member of both a distinctive occupation and organization and would likely use membership in both groups to create a professional work identity. This is because the individual will have perceived her organization and occupation to have cultivated congruent, distinguishing competencies and values. This notion is akin to what McLean Parks and Smith (2000) term pivotal identity space, a phenomenon that occurs when an organization's identity, for example, is affirmed to members through multiple ways or frames of communicating and experiencing it. When individuals perceive membership in both their organizations' and occupations' identities to offer enhanced status and distinction, these identities likely will share the same identity space in individuals' constructions and, as a result, will likely comprise a significant portion of their work identity.

Table 1

The role of distinction and status in creating an individual work identity

\begin{tabular}{llll}
\hline & Distinction and status of organization's identity & \\
\cline { 3 - 4 } & High & Low \\
\hline $\begin{array}{c}\text { Distinction and status of } \\
\text { occupation's identity }\end{array}$ & High & $\begin{array}{l}\text { Use membership in both the occupation and } \\
\text { organization to create an individual work identity } \\
\text { Use membership in the organization to create an } \\
\text { individual work identity }\end{array}$ & $\begin{array}{l}\text { Use membership in the occupation to } \\
\text { create an individual work identity } \\
\text { Use membership in other groups to } \\
\text { create an individual work identity }\end{array}$ \\
\hline
\end{tabular}

Alternatively, an individual could be a member of a low-status occupation in a low-status organization, such as a dishwasher at the local diner. In this type of situation, this individual would likely use non-work sources to construe an identity, or alternatively focus on the positive characteristics of the identity offered by his or her occupation or organization to find distinction and enhanced status. For example, New York City is known as a starting point for many struggling actors. These individuals often begin their careers as servers in restaurants. It is likely that being a member of a hospitality-based occupation in a hospitality organization has little to do with the work identity these individuals create for themselves. It is also possible that if these individuals quit their acting careers and instead pursue one of serving in restaurants, they could resolve the low status of their work by focusing on its positive, 
redeeming values, such as creating a positive experience for others, a process Ashforth and Kreiner (1999) term, reframing. In doing so, they will use the occupational and organizational identities of server in a particular restaurant to create their own individual work identities.

It is also possible that individuals might be members of organizations or occupations that offer conflicting identities and, as a result, individuals might simultaneously identify and disidentify with its membership, a condition termed schizo-identification (Dukerich et al., 1998). Thus, they perceive their occupation or organization to hold both positive and negative distinguishing values and/or competencies. For example, an individual could perceive her occupation of attorney to have a positive defining value of protecting the truth and a negative defining value of the profession always representing clients' interests even if these interests are self-serving and possibly bend or break the law. In creating a work identity, an individual will likely select the part of the group's identity that offers a more positive distinction (Ashforth \& Kreiner, 1999).

The more complex phenomenon exists when an individual is a member of a prestigious occupation, such as a profession, in a low-status organization or alternatively, is a member of a lowstatus occupation in a prestigious organization. For example, in the former case, an accounting professional might perceive his organization to be a small, low-level accounting firm that performs "cookie-cutter," routine tax returns. Alternatively, a lawyer working for an automobile manufacturer could perceive her bureaucratic company to offer her little status enhancement and possibly even a negative connotation with outsiders. Membership in the occupation or profession would offer higher levels of distinction, while membership in his organization, in contrast, would offer lower levels of and possibly even a negative distinction. Alternatively, an individual could perform low-status work in a highly prestigious organization, such as a housekeeper in one of the world's most renowned hotels. In such a situation, the person might strongly identify with membership in the organization and simultaneously reject or minimize the identity offered through membership in the occupation. In either case, individuals will likely disidentify with membership in the group that confers a low status or a negative distinction (Dukerich, Kramer, \& McLean Parks, 1998; Elsbach \& Bhattacharya, 2001; Pratt, 2000) and in doing so reject the associated identity it offers members.

Thus, we suggest that individuals will select membership in the group that confers what they perceive to be the greatest distinction and status enhancement. If the individual is a member of a professional group, his or her occupation will likely offer equal or greater distinction and status enhancement to that of his or her organization. However, if the individual is a member of low-status occupation, the likelihood exists that membership in the organization confers equal or greater 
distinction and status enhancement. Whether identities are held in a congruent manner or, alternatively, are in conflict, we argue that individuals will be attracted to the groups that confer a greater sense of distinction and status enhancement and will use membership in these groups to create their individual work identities (Ashforth \& Mael, 1989; Dutton et al., 1994; Turner, 1981). Stated more formally:

Proposition \#4: The group whose identity offers greater perceived distinction and status enhancement for its members, will act as a stronger source for members' individual work identities.

\section{Boundary Condition: The Role of Work Orientation}

While distinction and status enhancement likely make some group-identities stronger sources for work identity creation than others, we argue that an individual's work-orientation will dictate whether or not this process occurs. Wrzesniewski and colleagues (1997) have distinguished among the types of relationships people can have with their work; they term these work-orientations as jobs, careers, and callings. Those with a jobs work-orientation, such as many living-wage earners struggling to make ends meet, are primarily interested in their work as a means to obtain external rewards. Alternatively, those with a careers-orientation, such as many legal and financial services professionals, are more deeply invested in their work and occupation. Those with a callings work-orientation, such as many educators, missionaries or religious personnel, think of their work and life as inseparable (Wrzesniewski, McCauley, Rozin, \& Schwartz, 1997; Wrzesniewski, 2002).

Individuals who have a jobs work-orientation are less likely to care about creating an individual work identity because these individuals most typically view their jobs as a means to obtaining needed or valued returns or rewards. With such a view, these individuals are less likely to think of themselves in the context of performing their work. Not only would many individuals with living-wage type jobs likely fall into this category, but so would individuals who hold a job to pursue other passions or interests in their lives. Examples could be a convenience store clerk, an assembly-line worker, or a building security guard. Individuals holding these types of jobs are likely primarily interested in the wages they can earn to support their families and/or pursue other interests. Thus, those individuals with a jobs workorientation will likely construe a work identity, if at all, based on membership in other relevant social groups, such as for example, a group of co-workers or if relevant, union membership. As such we propose: 
Proposition \#5a: Individuals holding a jobs work-orientation are more likely to use membership in social groups more relevant than membership in their occupations or organizations to create their individual work identities.

Alternatively, those who have callings work-orientation, and view their work and life as inseparable, are likely to use membership in their occupation, or line of work, to construe their work identity. Examples could be individuals who do missionary work, those who assist the terminally ill in a hospice, or teachers of inner-city students. Such individuals are likely to view their work as their reason for being, and it likely shapes their entire self-concept. As a result, it is probable the organization acts as the vehicle or means for them to perform their work. For these individuals, it is also probable that their occupation would be the strongest source of their work identity. Thus, we offer:

Proposition \#5b: Individuals holding a callings work orientation are more likely to use membership in their occupations to create their individual work identities.

The more complex phenomenon may apply to both professional and non-professional individuals who view their work with a careers lens. These individuals consider their jobs to be part of a sequence of work experiences that over time, shape their self-concept, as it relates to the work they do (Arthur, Hall, \& Lawrence, 1989). Individuals can view their careers in two distinct ways. The first is through a more traditional model rooted in theories of adult development (i.e. Levinson, 1986; Super, 1957); the second is based on more recent concepts of the boundaryless career (Arthur \& Rousseau, 1996). The traditional model argues that during their lives individuals should progress through a series of jobs within one or a small number of organizations; over time they garner increasingly greater responsibilities and wider scopes of organizational influence. Individuals' career progression is linear, that is, they progress to higher levels in their chosen field while simultaneously assuming greater promotional and prestige opportunities within their organization's hierarchy (Rosenbaum, 1979; Schein, 1978; Spilerman, 1977). Individuals who view their careers with this more traditional lens are likely to view both their organizations and occupations as sources of their work identities and will tend to define themselves using their job titles in their organizations, such as a consulting partner with McKinsey and Company. For these individuals, distinction and status enhancement will likely determine which group identities will act as stronger sources in creating their work identities. Stated more formally:

Proposition \#5c: Depending on each group's perceived degree of distinction and status enhancement, individuals holding a traditional career perspective are more likely to use membership in both their organizations and occupations to create their individual work identities. 
We argue, however, that organizational membership will be less prominent for individuals who view their careers using a boundaryless perspective. "Boundaryless" refers to the notion that careers cross job and organizational borders (Arthur \& Rousseau, 1996) and in effect "zigzag" rather than proceed in a linear, hierarchical manner (Bateson, 1994). Thus, rather than remain with one organization and line of work over the course of their work life, individuals holding this perspective, self-manage their careers by autonomously capitalizing on new opportunities that they believe will provide them with valued returns in exchange for performance. As a result, individuals' relationships with their organizations are transactional and exchange-based (Blau, 1964), and their obligations to these organizations are short-term, indefinite, and contractually-oriented (McLean Parks, Kidder, \& Gallagher, 1998). These individuals exchange performance for marketable opportunities. Because their definition of success is individually constructed, notions of being on a "fast track" or a defined career path are less relevant and instead of job security, self-directed individuals seek to develop transferable skills to remain employable (Sullivan, Carden, \& Martin, 1998). In doing so, they likely develop an identity that is based not on their organizational membership but rather on the work that they do (Hall, 2002). For example, rather than say, "I work for the internet company, Smith Technologies," individuals with a boundaryless career perspective more likely say, "I do work with internet web-sites and search engines." Their identity is based on membership in their occupation. Based on these arguments we offer the final contextual proposition:

Proposition \#5d: Individuals holding a boundaryless career perspective are more likely to use membership in their occupations to create their individual work identities.

\section{Implications of Individual Work Identity}

In this article we have explored the process of creating an individual's work identity. The final question we consider is the following: What are the behavioral implications of holding a particular type of identity? To frame our ideas, we revisit central concepts from social identity theory.

Social identity research suggests that, as a way to place themselves and others in social groupings, individuals engage in a continuous process of comparing themselves with others. By placing themselves in particular groups, individuals place themselves out of other groups. Thus, identity provides distinction from out-group members (Ericson, 1980). Based on this distinction, individuals will think about and act differently toward members of their social groupings versus those who are not members. As a result, identities help impose social order through dictating the appropriate roles, thoughts, and behaviors associated with various sets of interactions individuals have with one another. 
As Wharton (1992, p. 65) suggested, "the behavioral consequences of social identity stem, in part, from its role as an organizing principle, imposing order on the various roles individuals play." This argument is echoed by symbolic interactionists, who argue that every interaction between two people involves role taking where, based upon their own identity, individuals form expectations about the other party (Goffman, 1959).

Thus, roles derived from their associated identities, provide individuals with a sense of meaning and purpose, as well as dictate how they can and should act, especially toward outgroup members (Hogg \& Abrams, 1988; Thoits, 1991). As individuals compare themselves against outgroup members, they develop a sense of what constitutes fair and just treatment that they should offer and expect from others (Kramer, 1991). For example, world famous physicians may think of themselves as experts and their patients as non-experts. Based on the roles associated with these identities, these physicians may expect that it is reasonable for patients to wait an hour or more for their time, even with scheduled appointments. These same physicians may find it unreasonable for patients to step out of a passive role and question the physician's expertise or not respect the physician's limited valuable time. Individuals who identify themselves as members of their organization or occupation likely form individual work identities that will influence the roles they expect themselves and outsiders or non-members, such as customers and clients, to adopt.

We suggest that roles, in turn, will likely influence behaviors individuals use to interact with outgroup members. These behaviors frame interactions these individuals have with others, such as clients, and can include such actions as ways individuals offer greetings, ask questions, make statements, demonstrate active listening techniques, handle interruptions, and end conversations. These behaviors can also include nonverbal actions, such as the use of eye-contact and proxemics, or ways individuals step into each other's personal space and physically position themselves in interactions. We suggest that these behaviors are based on the roles individuals enact when interacting with others. Returning to our example of a lawyer, if he thinks of himself as a skilled collaborator, very focused on working with clients to meet their unique set of needs, he would more likely exhibit more focused questioning and active listening techniques when interacting with them.

We offer these ideas as a way to introduce the next step in our thinking about an important behavioral implication of organizational identity, specifically job performance. Organizational members likely behave with crucial outsiders, such as clients or customers, according to the individual work identities they create for themselves and the associated roles these identities confer. Yet, as discussed, as part of the process of creating a work identity, an individual's occupation and organization can offer 
congruent or conflicting group identities. Aranya and Ferris's (1984) research supports the notion that such congruence and conflict exists; they found that organizational and professional conflict was lower in more professional accounting firms than in less professional ones. When their occupation and organization offer congruent identities, individuals will likely use the two sources to develop a strong work identity that dictates consistent roles and behaviors. For example, an academic working in a prestigious university is likely to think of himself as an intellectual. As a result, when interacting with out-group members such as clients or customers (which in this case would be students and perhaps their parents), an individual' roles and ultimately, job performance is more likely to be consistent and predictable.

However, if an individual's occupation and organization offer conflicting identities, and the individual perceives his or her occupational identity to provide greater distinction and status enhancement, and thus uses it to create an individual work identity, his or her work roles and job performance are more likely to be inconsistent with the expectations of the organization. For example, a physician who works for a for-profit health maintenance organization that asks her to restrict referrals may interact with patients at work in a manner that is not preferred by the organization. Her inconsistent job performance would emerge from the two identities that membership in her organization and occupation offers - a cost-efficient physician who works for the HMO and a caring physician who must thoroughly diagnose her patients' medical condition without limitations. Because it offers greater distinction and status enhancement, this physician is more likely to use her professional status to create her work identity when interacting with clients. Alternatively, she may try to resolve the conflict by interacting with her patients in ways that are dictated by both identities. In either situation she is likely behaving in ways that are not necessarily representative of the HMO's needs and desires. Based on these arguments, we offer the following:

Proposition \#6a: The more individuals perceive their occupational and organizational identities to be congruent, the more likely their job performance will be consistent with the organization's expectations.

Proposition \#6b: The more individuals perceive their occupational and organizational identities to be conflicted - and use their occupational identity to create their work identities - the more likely their job performance will be inconsistent with the organization's expectations.

Finally, we explore the behavioral implications of a second important human resource issue: turnover intentions. We have argued that individuals with a callings work-orientation and a boundaryless careers work-orientation are more likely to use membership in their occupations, and not 
their organizations, to create their individual work identity. The same possibility exists for individuals with a traditional careers work-orientation who more strongly identify with membership in their occupations. This phenomenon implies that individuals will seek employment in organizations that enable them to enact the roles associated with their occupational identities. For example, a university professor who adopts the identity of "researcher" and "creator of new knowledge" associated with membership in the academic profession, would likely prefer to work in a university that supports research activities, rather than at a teaching college that requires a heavy course load. If the professor can find a university that supports the roles associated with this sort of identity, then she is less likely to leave her job and university to find a better fit. To support these identities would mean that the organization would provide the resources, such as training and financial outlay, that enable individuals to perform their work, as well as the recognition that their performance is valued. This logic is in line with Ashforth and Mael's (1989) claim that individuals would support institutions that embody their identities.

In addition, our arguments are akin to work on job and organizational embeddedness (Mitchell, Holton, Lee, Sablynski, \& Erez, 2001; Ng \& Feldman, 2007). Both job and organizational embeddedness refer in part, to the extent to which an individual's job and organization is compatible or fits with other aspects of the individual's life, including an individual's personal values and career goals. Mitchell et al. (2001) found that those who are more embedded to their jobs are less likely to leave their organizations. In a similar manner, we suggest that individuals' turnover intentions will be lower if they can find employment with organizations that enable them to enact the roles associated with their occupational identities. While not identical to personal values and career goal concepts, occupational roles are embedded in an individual's wider view of the work they do and are likely to drive individuals' searches for compatible organizations. Thus, the logic embedded in our arguments runs similar to that of job and organizational embeddedness; that is, individuals will likely seek membership in organizations that offer jobs or work congruent with the roles of their wider profession. Stated more formally:

Proposition \#7: For individuals who use membership in their occupations to create their individual work identities, the more they perceive their organizations to support the roles associated with their individual work identities, the lower their turnover intentions are likely to be.

\section{Implications for Organizational Identity Theory}

One major objective of this article has been to develop the link between an organization's identity and the implications for its members, specifically for the ways members think about themselves 
in the context of their work. Our goal has been to explore how and why an organization's identity is incorporated into a member's own work identity and potential implications of this process for organizations. In this final section we address the theoretical contributions of our work.

Researchers have acknowledged that individuals hold multiple identities about their organizations and that these identities influence ways members approach their work (Ashforth \& Mael, 1996; Foreman \& Whetten, 2002; Pratt \& Foreman, 2000). Yet, researchers in our field have yet to consider what these identities are and how, based on their potential to be in congruence or conflict, they are individually enacted (Ashforth \& Mael, 1993). This article considers these complex issues. Through applying concepts from social identity theory and developing the construct of individual work identity, we build the connection between ways members construe their organization's identity and potential outcomes for these members as it relates to their job performance and turnover intentions. Moreover, we bring a key non-organizational identity into the process and show how members can reach beyond their organizations to incorporate identification with their occupations into their individual work identity. Thus, this research considers not only why individuals identify with membership in their organizations and occupations, but perhaps more interestingly, the impact and resolution of their potential congruence and conflict. In addition, by focusing on the different types of work-orientations individuals may hold, we contextualize and provide greater depth to our arguments.

This work has potential implications not only for research in organizational identity, but also for research that explores the impact of human resource initiatives. For example, the strength of organizational versus occupational identity on individual identity creation may determine whether individuals develop a local or cosmopolitan orientation (Gouldner, 1957). Such an orientation might in turn, determine whether individuals will develop a sense of organizational commitment and job satisfaction that is manifest in their interactions with an organization's customers and clients (Gouldner, 1958). In addition, while some prior research has considered the presence of occupational identities (i.e. Ashforth \& Kreiner, 1999; Kreiner, Ashforth, \& Sluss, 2006), as well as the notion that organizational members' interactions with out-group members may affect their organizational identification (i.e. Bartel, 2001), few studies have explored the notion of multiple foci of identification at the organizational and occupational levels. In addition, those that have (i.e. van Dick, Wagner, Stellmacher, \& Christ, 2005, van Dick, Wagner, Stellmacher \& Christ, 2004; Dukerich, Golden, \& Jacobson, 1996; Johnson et al., 2006) identified the presence of multiple identities to delineate which identities are more salient. We offer rationale as to why at least for an individual's organization and occupation, the identity offered by membership in one of these two groups may be more salient than the other. By considering the 
implications of the salience of organizational and occupational identities together, on job performance and turnover intentions, we add texture to Gouldner's (1958) arguments, offering reasons as to why individuals may hold a local or cosmopolitan orientation. We also contribute to work on multiple foci of identification, exploring the potential outcomes of identifying with membership in multiple groups for both individuals and their organizations.

For example, our ideas suggest that professionals, versus individuals who are members of other lower-status occupational groups, are more likely to reach beyond their organizations when creating their individual work identity. These individuals may have a callings work-orientation or, alternatively, be adopting a boundaryless career strategy. Organizations may wish to ensure that these individuals receive the career planning and mentoring that would enable them to comfortably enact their identities inways that are consistent with the organizations' needs and expectations. By doing so, these organizations may increase their chances of these individuals developing their careers in-house, as longterm, loyal employees.

Future research could explore both theoretical and empirical extensions of the ideas presented here. While this article has offered propositions about the development and enactment of work identity, future research needs to develop a series of related hypotheses and then test them. Focusing initially on one type of organization and occupation, such as accountants, physicians, or attorneys, would represent a good beginning point; expanding the initial sample to other types of organizations and occupations and exploring the implications of more and less professional occupations and organizations, with varying degrees of cultural controls, could occur subsequently. Future research could also consider the impact of employment in a bureaucratic organization, such as an in-house lawyer who works for the government or other large, mechanistic organization, versus a professional firm, whereby most members also belong to the same occupational group.

This article has suggested that work identity draws from multiple sources. We have looked specifically at two of the more likely sources - organizational identity and occupational identity. Yet, we examined membership in these two work groups at the expense of other potentially relevant ones, such as those based on race, age, and gender. Subsequent research could consider the influence of membership in other important social groups on individual work identity. In addition, we have treated an organization's identity as a unitary concept, largely ignoring the possibility that nested identities exist within the organization (Pratt \& Foreman, 2000). Future research needs to consider the influence of identities associated with membership in particular work groups or other work units within the organization, further developing and exploring the implications of holding multiple, nested identities. 
Finally, we present our arguments at one point in time. Yet, throughout this article, we have argued that identities shift, depending on the people with whom the individual interacts. Research, such as the work completed by Gioia, Schultz, and Corley (2000), that suggests identification with an organization is a fluid, unstable, and mutable construct, causes us to also ask how individual's work identities might shift. Can, for example, individuals be chameleon-like and shift identities as the need arises? What cognitive processes aid in the shift? How might their behaviors be different as a result? How might this shift affect the credibility so important to individuals' reputations? Work identity has critical implications for ways that work is accomplished at both the individual and organizational levels; it is a construct that calls for further investigation. We offer what we hope are provocative ideas that link a crucial social identification process with important outcomes for organizations.

\section{Conclusion}

Work identity is a major part of the overall identity of many adults. Yet little research has examined the concept of individual work identity, which impacts the way people think and act in the context of their work. We have examined the process by which individuals use membership in two of their important work-based social groups to create their individual work identities. We explored the complexities of using membership in both groups to create an individual work identity and we considered the role of one's work-orientation. Specifically, we considered the impact of a boundaryless careers work-orientation on the identity-creation process. Finally, we explored the implications of holding a work identity for the roles individuals adopt and their associated behaviors they use when interacting with outsiders. We focused on two specific and important organizational outcomes: job performance and turnover intentions. In doing so, we link organizational identity with important outcomes for both the organization and its members.

\section{References}

Abrams, D., \& Hogg, M. A. (1990). An introduction to the social identity approach. In D. Abrams, \& M. A. Hogg (Eds.), Social identity theory: Constructive and critical advances (pp. 1-9). New York: Springer-Verlag.

Adler, P. A., \& Adler, P. (1988). Intense loyalty in organizations: A case study of college athletics. Administrative Science Quarterly, 33, 401-417.

Albert, S. (1998). The definition and measurement of identity. In D. A. Whetten, \& P. C. Godfrey (Eds.), Identity in organizations (pp. 1-13). Thousand Oaks, CA: Sage. 
Albert, S., \& Whetten, D. A. (1985). Organizational identity. In L. L. Cummings, \& B. M. Staw (Eds.), Research in organizational behavior, Vol. 7. (pp. 263-295). Greenwich, CT: JAI Press.

Arayna, N., \& Ferris, K. R. (1984). A reexamination of accountants' organizational-professional conflict. The Accounting Review, 24, 1-15.

Arthur, M. B., Hall, D. T., \& Lawrence, B. S. (1989). Handbook of career theory. New York: Cambridge University Press.

Arthur, M. B., \& Rousseau, D. M. (1996). The boundaryless career: A new employment principle for a new organizational era. New York: Oxford University Press.

Ashforth, B. E., \& Kreiner, G. E. (1999). How can you do it? Dirty work and the challenge of constructing a positive identity. Academy of Management Review, 24, 413-434.

Ashforth, B. E., \& Mael, F. A. (1989). Social identity theory and the organization. Academy of Management Review, 14, 20-39.

Ashforth, B. E., \& Mael, F. A. (1993). Emotional labor in service roles: The influence of identity. Academy of Management Review, 18, 88-115.

Ashforth, B. E., \& Mael, F. A. (1996). Organizational identity and strategy as a context for the individual. In P. Shrivastava. In A. S. Huff, \& J. E. Dutton (Eds.), Advances in Strategic Management, Vol. 13. (pp. 19-64). Greenwich, CT: JAI Press.

Barker, J. R. (1998). Managing identification. In D. A. Whetten, \& P. C. Godfrey (Eds.), Identity in organizations (pp. 257-267). Thousand Oaks, CA: Sage Publications.

Barley, S. R. (1996). Technicians in the workplace: Ethnographic evidence for bringing work into organization studies. Administrative Science Quarterly, 41, 404-441.

Barney, J. B. (1991). Firm resources and sustained competitive advantage. Journal of Management, 17, 99-120.

Bartel, C. A. (2001). Social comparisons in boundary-spanning work: Effects of community outreach on members' organizational identity and identification. Administrative Science Quarterly, 46, 379-413.

Bateson, M. C. (1994). Peripheral visions: Learning along the way. New York: Harper-Collins.

Bhattacharya, C. B., Rao, H., \& Glynn, M. A. (1995). Understanding the bond of identification: An investigation of its correlates among art museum members. Journal of Marketing, 59, 46-58.

Blau, P. M. (1964). Exchange and power in social life. New York: John Wiley \& Sons, Inc.

Brewer, M. B. (1991). The social self: On being the same and different at the same time. Personality and Social Psychology Bulletin, 17, 475-482. 
Charon, J. M. (1992). Symbolic interactionism. Englewood Cliffs, NJ: Prentice-Hall.

Coff, R. W. (1997). Human assets and management dilemmas: Coping with hazards on the road to resource-based theory. Academy of Management Review, 22, 374-402.

Conlon, E. J., \& Gallagher, D. G. (1987). Commitment to employer and union: Effects of membership status. Academy of Management Journal, 30, 151-162.

Corley, K. G. (2004). Defined by our strategy or our culture? Hierarchical differences in perceptions of organizational identity and change. Human Relations, 57, 1145-1177.

Corley, K. G., Harquail, C. V., Pratt, M. G., Glynn, M. A., Fiol, C. M., \& Hatch, M. J. (2006). Guiding organizational identity through aged adolescence. Journal of Management Inquiry, 15, 85-99.

Covaleski, M. A., Dirsmith, M. W., Heian, J. B., \& Samuel, S. (1998). The calculated and the avowed: Techniques of discipline and struggles over identity in Big Six public accounting firms. Administrative Science Quarterly, 43, 293-327.

Dukerich, J. M., Golden, B. R., \& Jacobson, C. K. (1996). Nested cultures and identities: A comparative study of nation and professional/occupation status effects on resource allocation decisions. In P. A. Bamberger, M. Erez, \& S. B. Bacharach (Eds.), Research in the sociology of organizations, Vol. 14. (pp. 35-89). Greenwich, CT: JAI Press.

Dukerich, J. M., Golden, B. R., \& Shortell, S. M. (2002). Beauty is in the eye of the beholder: The impact of organizational identification, identity and image on the cooperative behaviors of physicians. Administrative Science Quarterly, 47, 507-533.

Dukerich, J. M., Kramer, R., \& McLean Parks, J. (1998). The dark side of organizational identification. In D. A. Whetten, \& P. C. Godfrey (Eds.), Identity in organizations (pp. 245-256). Thousand Oaks, CA: Sage.

Dutton, J. E., Dukerich, J. M., \& Harquail, C. V. (1994). Organizational images and member identification. Administrative Science Quarterly, 39, 239-263.

Dutton, J. E., \& Penner, W. J. (1993). The importance of organizational identity for strategic agenda building. In J. Hendry, \& G. Johnson (Eds.), Strategic thinking: Leadership and the management of change (pp. 89-113). New York: John Wiley \& Sons.

Elsbach, K. D. (1998). The process of social identification: With what do we identify? In D. A. Whetten, \& P. C. Godfrey (Eds.), Identity in organizations (pp. 232-237). Thousand Oaks, CA: Sage.

Elsbach, K. D. (2003). Relating physical environment to self-categorizations: Identity threat and affirmation in a non-territorial office space. Administrative Science Quarterly, 48, 622-654. 
Elsbach, K. D. (2004). Interpreting workplace identities: The role of office décor. Journal of Organizational Behavior, 25, 99-128.

Elsbach, K. D., \& Bhattacharya, C. B. (2001). Defining who you are by what you're not: Organizational disidentification and The National Rifle Association. Organization Science, 12, 393-413.

Ericson, E. H. (1980). Identity and the life cycle. New York: Norton.

Fine, M. (1994). Working the hyphens: Reinventing self and other in qualitative research. In N. K. Denzin, \& Y. S. Lincoln (Eds.), Handbook of qualitative research (pp. 70-97). Thousand Oaks, CA: Sage.

Foreman, P., \& Whetten, D. A. (2002). Members' identification with multiple-identity organizations. Organization Science, 13, 618-635.

Fuller, J. B., Hester, K., Barnett, T., Frey, L., Relyea, C., \& Beu, D. (2006). Perceived external prestige and internal respect: New insights into the organizational identification process. Human Relations, $59,815-846$.

Gergen, K. (1991). The saturated self. New York: Basic Books.

Gioia, D. A., Schultz, M., \& Corley, K. G. (2000). Organizational identity, image and adaptive instability. Academy of Management Review, 25, 63-81.

Gioia, D. A., \& Thomas, J. B. (1996). Identity, image and issue interpretation: Sensemaking during strategic change in academia. Administrative Science Quarterly, 41, 370-403.

Glynn, M. A. (2000). When cymbols become symbols: Conflict over organizational identity within a symphony orchestra. Organization Science, 11, 285-298.

Goffman, E. (1959). The presentation of self in everyday life. Garden City, NY: Doubleday.

Golden-Biddle, K., \& Rao, H. (1997). Breaches in the boardroom: Organizational identity and conflicts of commitment in a nonprofit organization. Organization Science, 8, 593-611.

Gouldner, A. W. (1957). Cosmopolitans and locals: Toward an analysis of latent social roles-I. Administrative Science Quarterly, 2, 281-306.

Gouldner, A. W. (1958). Cosmopolitans and locals: Toward an analysis of latent social roles-II. Administrative Science Quarterly, 2, 444-480.

Grey, C. (1988). On being a professional in a "big six" firm. Accounting, Organizations and Society, 23, 569-587.

Grover, S. L. (1993). Why professionals lie: The impact of professional role conflict on reporting accuracy. Organizational Behavior and Human Decision Processes, 55, 251-272.

Hall, D. T. (2002). Careers in and out of organizations. Thousand Oaks, CA: Sage Publications.

Hewitt, J. P. (1989). Dilemmas of the American self. Philadelphia: Temple University Press. 
Hogg, M. A., \& Abrams, D. (1988). Social identifications. New York: Routledge, Chapman and Hall. Hogg, M. A., \& McGarty, C. (1990). Self categorization and social identity. In D. Abrams, \&M. A. Hogg (Eds.), Social identity theory: Constructive and critical advances (pp. 10-27). New York: SpringerVerlag.

Hogg, M. A., \& White, D. J. (1995). A tale of two theories: A critical comparison of identity theory with social identity theory. Social Psychology Quarterly, 58, 255-269.

Johnson, M. D., Morgeson, F. P., Ilgen, D. R., Meyer, C. J., \& Lloyd, J. W. (2006). Multiple professional identities: Examining differences in identification across work-related targets. Journal of Applied Psychology, 91, 498-506.

Katz, D., \& Kahn, R. L. (1966). The social psychology of organizations. New York: Wiley.

Kramer, R. M. (1991). Intergroup relations and organizational dilemmas: The role of categorization processes. In B. M. Staw, \& T. G. Cummings (Eds.), Research in organizational behavior, Vol. 13. (pp. 191-228). Greenwich, CT: JAI Press.

Kramer, R. M., \& Brewer, M. B. (1984). Effects of group identity on resource use in a simulated commons dilemma. Journal of Personality and Social Psychology, 46, 1044-1057.

Kreiner, G. E., \& Ashforth, B. E. (2004). Evidence toward and expanded model of organizational identification. Journal of Organizational Behavior, 25, 1-27.

Kreiner, G. E., Ashforth, B. E., \& Sluss, D. M. (2006). Identity dynamics in occupational dirty work: Integrating social identity and system justification perspectives. Organization Science, 17, 619-636.

Levinson, D. (1986). A conception of adult development. American Psychologist, 41, 3-13.

Mael, F. A., \& Ashforth, B. E. (1992). Alumni and their alma mater: A partial tests of the reformulated model of organizational identification. Journal of Organizational Behavior, 13, 103-123.

Mael, F. A., \& Ashforth, B. E. (1995). Loyal from day one: Biodata, organizational identification and turnover among newcomers. Personnel Psychology, 48, 309-333.

Mahoney, J. T., \& Pandian, R. (1992). The resource-based view within the conversation of strategic management. Strategic Management Journal, 13, 363-380.

McLean Parks, J., Kidder, D., \& Gallagher, D. G. (1998). Fitting square pegs into round holes: Mapping the domain of contingent work arrangements onto the psychological contract. Journal of Organizational Behavior, 19, 697-730.

McLean Parks, J. \& Smith, F.L. (2000). Organizational identity: The ongoing puzzle of definition and redefinition. Paper presented at the Academy of Management Meeting, Toronto, CA. 
Mitchell, T. R., Holtom, B. C., Lee, T. W., Sablynski, C. J., \& Erez, M. (2001). Why people stay: Using job embeddedness to predict voluntary turnover. Academy of Management Journal, 44, 1102-1121.

Nelson, R. R., \& Winter, S. G. (1982). An evolutionary theory of economic change. Cambridge, MA: Harvard University Press.

Ng, T. W. H., \& Feldman, D. C. (2007). Organizational embeddedness and occupational embeddedness across career stages. Journal of Vocational Behavior, 70, 336-351.

O'Reilly, C., \& Chatman, J. (1986). Organizational commitment and psychological attachment: The effects of compliance, identification and internalization on prosocial behavior. Journal of Applied Psychology, 71, 492-499.

Peteraf, M. A. (1993). The cornerstones of competitive advantage: A resource based view. Strategic Management Journal, 14, 179-191.

Pettigrew, T. F. (1986). The intergroup contact proposition reconsidered. In M. Hewstone, \& R. Brown (Eds.), Contact and conflict in intergroup encounters (pp. 169-195). New York: Basil Blackwell.

Prahalad, C. K., \& Hamel, G. (1990, May-June). The core competence of the corporation. Harvard Business Review, 79-91.

Pratt, M. G. (1998). To be or not to be? Central questions in organizational identification. In D. A. Whetten, \& P. C. Godfrey (Eds.), Identity in organizations: Building theory through conversations (pp. 171-207). Thousand Oaks, CA: Sage.

Pratt, M. G. (2000). The good, the bad and the ambivalent: Managing identification among Amway distributors. Administrative Science Quarterly, 45, 456-493.

Pratt, M. G., \& Foreman, P. O. (2000). Classifying managerial responses to multiple organizational identities. Academy of Management Review, 25, 18-42.

Reichers, A. E. (1985). A review and reconceptualization of organizational commitment. Academy of Management Review, 10, 465-476.

Rindova, V. P., \& Schultz, M. (1998). Identity within and identity without: Lessons from corporate and organizational identity. In D. A. Whetten, \& P. C. Godfrey (Eds.), Identity in organizations: Building theory through conversations (pp. 46-51). Thousand Oaks, CA: Sage.

Rosenbaum, J. E. (1979). Tournament mobility: Career patterns in a corporation. Administrative Science Quarterly, 24, 220-241.

Russo, T. C. (1998). Organizational and professional identification: A case of newspaper journalists. Management Communication Quarterly, 1, 72-111. 
Schein, E. H. (1978). Career dynamics: Matching individual and organizational needs. Reading, MA: Addison-Wesley.

Scott, S. G., \& Lane, V. R. (2000). A stakeholder approach to organizational identity. Academy of Management Review, 25, 43-62.

Spilerman, S. (1977). Careers, labor market structure and socioeconomic achievement. American Journal of Sociology, 83, 551-593.

Sullivan, S. E., Carden, W. A., \& Martin, D. F. (1998). Careers in the next millennium: Directions for future research. Human Resource Management Review, 8, 165-185.

Super, D. (1957). Psychology of careers. New York: Harper \& Brothers.

Tajfel, H. (1982). Social identity and intergroup relations. Cambridge: Cambridge University Press.

Tajfel, H., \& Turner, J. C. (1985). The social identity theory of intergroup behavior. In S. Worchel, \& W. G. Austin (Eds.), Psychology of intergroup relations (pp. 7-24)., 2nd ed. Chicago: Nelson-Hall.

Thoits, P. A. (1991). On merging identity theory and stress research. Social Psychological Quarterly, 54, 101-112.

Trice, H. M. (1993). Occupational subcultures in the workplace. Ithaca, New York: ILR Press.

Turner, J. C. (1981). The experimental social psychology of intergroup behavior. In J. C. Turner, \& H. Giles (Eds.), Intergroup behavior (pp. 66-101). Chicago: University of Chicago Press.

Turner, J. C. (1982). Towards a cognitive redefinition of the social group. In H. Tajfel (Ed.), Social identity and intergroup relations (pp. 15-40). Cambridge, England: Cambridge University Press.

Turner, J. C., Hogg, M. A., Oakes, P. J., Reicher, S. D., \& Wetherell, S. D. (1987). Rediscovering the social group: A self-categorization theory. Oxford: Blackwell.

Tyler, T. R. (1999). Why people cooperate with organizations: An identity-based perspective. In R. I. Sutton, \& B. Staw (Eds.), Research in organizational behavior, Vol. 21. (pp. 210-247). Greenwich, CT: JAI Press.

van Dick, R., Wagner, U., Stellmacher, J., \& Christ, O. (2004). The utility of a broader conceptualization of organizational identification: Which aspects really matter? Journal of Occupational and Organizational Psychology, 77, 171-191.

van Dick, R., Wagner, U., Stellmacher, J., \& Christ, O. (2005). Category salience and organizational identification. Journal of Occupational and Organizational Psychology, 78, 273-285.

Van Knippenberg, D., \& van Schie, E. C. M. (2000). Foci and correlates of organizational identification. Journal of Occupational and Organizational Psychology, 73, 137-147. 
Van Maanen, J., \& Barley, S. R. (1984). Occupational communities: Control in organizations. In B. M. Staw, \& L. L. Cummings (Eds.), Research in organizational behavior, Vol. 6. (pp. 287-365). Greenwich, CT: JAI Press.

Van Maanen, J., \& Schein, E. H. (1979). Toward a theory of organizational socialization. In B. M. Staw, \& L. L. Cummings (Eds.), Research in organizational behavior, Vol. 1. (pp. 209-264). Greenwich, CT: JAI Press.

Wallace, J. E. (1993). Professional and organizational commitment: Compatible or incompatible? Journal of Vocational Behavior, 42, 333-349.

Wallace, J. E. (1995). Organizational and professional commitment in professional and nonprofessional organizations. Administrative Science Quarterly, 40, 228-255.

Wharton, A. S. (1992). The social construction of gender and race in organizations: A social identity and group mobilization perspective. In P. Tolbert, \& S. B. Bacharach (Eds.), Research in the sociology of organizations, Vol. 10. (pp. 55-84). Greenwich, CT: JAI Press.

Whetten, D. A. (2006). Albert and Whetten revisited: Strengthening the concept of organizational identity. Journal of Management Inquiry, 15, 219-234.

Wrzesniewski, A. (2002). "It's not just a job" Shifting meanings of work in the wake of 9/11. Journal of Management Inquiry, 11, 230-234.

Wrzesniewski, A., McCauley, C., Rozin, P., \& Schwartz, B. (1997). Jobs, careers and callings: People's relations to their work. Journal of Research in Personality, 31, 21-33.

Zola, I., \& Miller, S. J. (1973). The eroding of medicine from within. In E. Freidson (Ed.), Professions and their prospects (pp. 153-172). Beverly Hills: Sage. 